\title{
Review
}

\section{CLINICAL ASPECTS OF PROTEIN DEFICIENCY WITH SPECIAL REFERENCE TO PROTEIN CALORIE MALNUTRITION (PCM) IN CHILDREN}

\author{
Ousa Thanangkul, Damri Damrongsak, \\ Vicharn VITHAYASAI, and Robert E. OLSON \\ Anemia and Malnutrition Research Center (MALAN), \\ Chiang Mai Medical College and St. Louis University School of Medicine, \\ Chiang Mai, Thailand
}

(Received March 4, 1980)

Keywords protein deficiency, kwashiorkor, marasmus, vitamin deficiency, hypoproteinemia, anemia

In the clinical scene protein deficiency cannot be considered in isolation, especially where children are concerned. It is usually seen in association with other deficiency states (calories, vitamins, and minerals) and often with severe infections, to present the classic picture of a child suffering from protein calorie malnutrition (PCM) with associated complications.

Protein calorie malnutrition (PCM) is a disease of multiple etiology, observed mainly in developing countries where the available food has only a marginal calorie and protein content. It mostly affects children under the age of 5 years, and is complicated by infections and mineral and vitamin deficiencies. The term "Protein Calorie Malnutrition" was proposed by the Sixth FAO/WHO Joint Committee ( 1 ) in 1962 to cover the whole spectrum of protein and calorie deficiency when the two extreme forms of PCM were recognized as marasmus and kwashiorkor.

Since 1967 this disease has been studied at the Anemia and Malnutrition Research Center (MALAN) in Chiang Mai, Thailand. We have investigated its pathogenesis (including clinical, biochemical, and hematological aspects) among children. We have also sought an optimum therapy for our PCM patients, both as regards their protein and calorie requirements, and their needs for minerals, vitamins, and antibiotics. This has reduced mortality among our patients from about $30 \%$ (1968) to its present level of $6-7 \%$. The readmission rate is only $1 \%$. This article relies heavily on the work just described which was funded in part by the US National Institutes of Health as well as by the Royal Thai Government.

\section{Pathogenesis of protein calorie malnutrition}

Views on this subject differ widely. In 1966 McCance and Widdowson(2) reported, on the basis of animal studies, that in animals and human subjects one 
could distinguish between protein and calorie deficiencies. They concluded that marasmus is a calorie deficiency and kwashiorkor a protein deficiency. In 1967 Gopalan (3) stated that he found no definite difference between the dietary patterns of children who developed kwashiorkor and of those who developed marasmus. He postulated that the body's extent of adaptation to protein and calorie-deficient diets, as influenced by their degree and duration, is the factor which leads to a consequential change of the hormonal balance and is thus responsible for metabolic changes in the body. Failure to adapt would lead to the development of kwashiorkor. Children with extreme adaptation would develop marasmus.

Hormonal factors involved in this adaptation are not clear. Waterlow and Stephen in 1966 (4) suggested a possible role for insulin. Pimstone, 1966(5) reported a raised growth hormone level in kwashiorkor. Möckenberg, 1963(6) showed that marasmic children who failed to gain weight, even when receiving $120 \mathrm{Cal} / \mathrm{kg} \mathrm{b.w.,}$ showed good body weight gain after receiving an injection of human growth hormone. Rao, 1974(7) suggested that the development of the contrasting syndromes of kwashiorkor and marasmus in children with protein calorie malnutrition is due solely to a variable response of the adrenal cortex in adapting to the same dietary stress. Whitehead et al. (8) in 1976 have suggested that there are many factors other than dietary protein or energy which influence the form of protein calorie malnutrition. His study also supported the hypothesis that hormones, such as insulin and cortisol, might be among them. It is our view that both environmental and host factors must be considered.

Near-starvation appears to be the cause of marasmus. The symmetrical decrease in all dietary nutrients, including calories, causes the child to consume his own tissue as a source of nutrient. This equally scarce, but nutritious fare prevents the development of specific deficiency signs, although total energy expenditure falls as the total body mass shrinks (9). All of the endocrine adjustments to fasting occur as shown in Fig. 1. Under the influence of somatotropin, corticoids, and glucagon, fatty acids are mobilized from adipose tissue and amino acids from muscular tissue. Hepatic gluconeogenesis is enhanced and plasma proteins are maintained near normal concentration. No edema occurs as long as the cardiac index is sufficient to provide adequate renal perfusion.

When children consume a diet more adequate in calories but still limited in protein, a different endocrine adjustment occurs. Alleyne and Young (10) and Rao et al.(11) have shown that although cortisol levels are raised in kwashiorkor, they are much higher in marasmus. It appears to us that it is not the adaptation of the adrenal cortex in kwashiorkor that is defective, but rather that a powerful stimulus to the hypothalamus provided by lack of calories is absent, and makes the adaptation different.

The hypothalamic-pituitary-adrenal axis seems to sense calorie restriction much better than protein restriction. In the presence of more calories, the mobilization of fatty acids from depot fat and amino acids from muscle does not occur to the same extent. As a result of the amino acid deficit, the synthesis of 


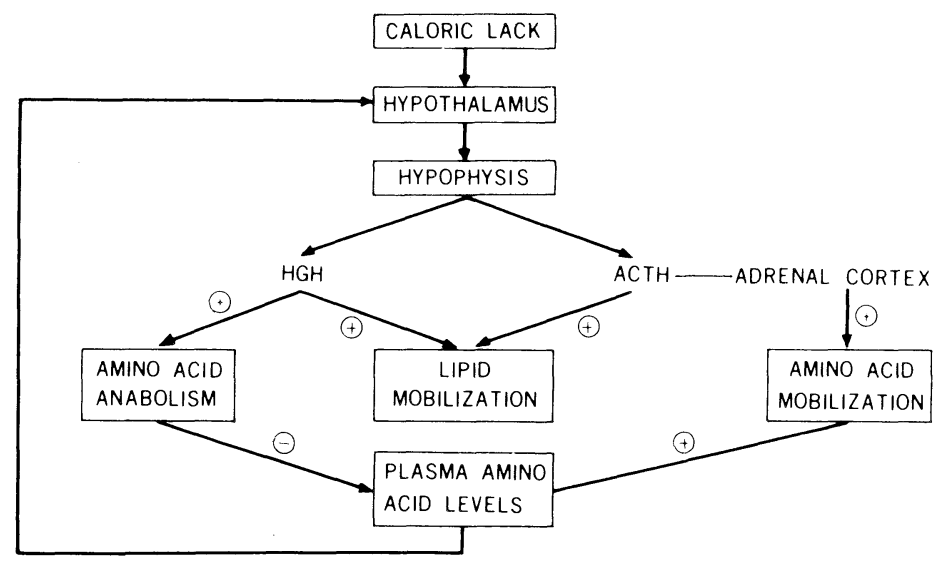

Fig. 1. Regulation of metabolites in protein calorie malnutrition.

plasma proteins (particularly albumin) falls with a corresponding fall in oncotic pressure. Extracellular water accumulates, tissue pressure rises and cardiac output falls, renin is synthesized by the kidney, and the resulting aldosterone further enhances sodium retention which further dilutes the plasma proteins. This situation does not differ in its essential elements from that seen in edematous states associated with chronic liver disease, in which the deficit is not due to a deficiency of amino acids but a destruction of the reticulum of the liver with a consequent reduction in its ability to synthesize plasma proteins at the required rate (12).

It appears that there are genuine differences in the distribution of marasmus and kwashiorkor in different parts of the world. In Lebanon and $\operatorname{Iraq}(13,14)$ about $90-95 \%$ of children with PCM are marasmic, whereas in Africa kwashiorkor predominates in Uganda and marasmus in Gambia (8). In Thailand, essentially equal numbers of children are found with marasmus, marasmic kwashiorkor, and kwashiorkor (15).

\section{Classification of protein calorie malnutrition}

The classification of Gomez and Frank for PCM (16), introduced in 1955, has been extensively used. It is based upon an age-related body weight deficit. Waterlow (17-19) has suggested that the weight for height is a better index of the current stage of malnutrition in the child than the weight for age.

The question arises as to what standard should be used as a reference for weight and height. It has been shown that the average weight and height of Northern Thai children is equal to the tenth percentile of the Harvard standard (20). Habicht et al. have demonstrated that there is no basic difference in the genetic potential for growth in different races $(21)$. It is therefore appropriate that an international standard be adopted, and the one most widely used internationally 
is the Harvard standard. Van Wieringen (22) has furthermore shown that above the age of 1 year, weight at any given height is independent of age.

The Working Party sponsored by the Wellcome Trust, which met in Jamaica in 1970 to discuss the classification of infantile malnutrition(23), suggested that weight for age by the Harvard standard should be used. They concluded that the diagnosis of marasmus should be applied to children who are less than $60 \%$ of the expected weight for a particular age, and without edema; that marasmic kwashiorkor should be applied to those less than $60 \%$ of the expected weight, but with edema; and that the term kwashiorkor be applied to children with edema who were above $60 \%$ of expected weight for age. It is our experience that this classification tends to put patients with kwashiorkor into the marasmic kwashiorkor group. Diagnosis of kwashiorkor is underestimated, simply because average Northern Thai children are smaller than the Harvard standard growth chart indicates. This same situation also applies to the Gomez classification which is based on the degree to which the child's weight for age differs from the accepted standard. Those children who are stunted but not wasting would be classified as severely protein-calorie-malnourished, which is a disadvantage for judging their present nutritional status.

For the past several years we have employed the criteria of McLaren (24) for the classification of PCM between marasmus, marasmic kwashiorkor, and kwashiorkor. We have modified his system, however, first by clinical estimates of anthropometric data, and later with a quantitative scoring system as shown in Table 1. The purpose of our classification is to ascertain PCM differences mainly in the clinical and hospital setting. Our system aims to classify PCM qualitatively, so as to help to rate the clinical severity and mortality of the different types of protein calorie malnutrition.

It employs anthropometric, clinical, and biochemical data. We have used percentage weight for height as the most representative indication of general nutritional status, corrected for the presence of edema. The score is high when edema is present. For clinical data, we have used dermatosis as a reliable indicator of kwashiorkor, commonly associated with severe PCM and have attached significant weight to its presence. Scores for serum albumin are modified slightly from McLaren's system. Some patients were edematous prior to admission, but shed their edema on admission. In this type of patient, the association of low serum albumin would convey a bad prognosis. According to those criteria, marasmus is diagnosed when the score is between 1 and 3; marasmic kwashiorkor when it is between 4 and 7; and kwashiorkor when it is over 8 .

Since growth potential will be attained to differing extents in different communities, it seems desirable to eliminate from the diagnosis of acute malnutrition the dwarfing effect of children of normal proportions. It is clear, of course, that dwarfing may be the result of modest long-term chronic malnutrition. Consequently, the expected weight for height should be the criterion of choice. As Van Wieringen (22) has shown among Dutch children, the weight at a given height is 
Table 1. Scoring for PCM.

\begin{tabular}{|c|c|c|}
\hline & & Score \\
\hline $\mathrm{Wt} / \mathrm{Ht}$ & $80 \%$ with edema & 5 \\
\hline $\mathrm{Wt} / \mathrm{Ht}$ & Between $70-80 \%$ with edema & 4 \\
\hline $\mathrm{Wt} / \mathrm{Ht}$ & Below $70 \%$ with edema & 3 \\
\hline $\mathrm{Wt} / \mathrm{Ht}$ & Below $70 \%$ without edema & 1 \\
\hline $\mathrm{Wt} / \mathrm{Ht}$ & $70 \%$ without edema & 0 \\
\hline Dermatosis & & 3 \\
\hline Serum albumin & Serum protein & \\
\hline$-1.00 \mathrm{~g} / 100 \mathrm{ml}$ & $-3.25 \mathrm{~g} / 100 \mathrm{ml}$ & 5 \\
\hline $1.00-1.49$ & $3.25-3.99$ & 4 \\
\hline $1.50-1.99$ & $4.00-4.74$ & 3 \\
\hline $2.00-2.49$ & $4.75-5.49$ & 2 \\
\hline $2.50-2.99$ & $5.50-6.24$ & 1 \\
\hline 3.00 & 6.25 & 0 \\
\hline Score for $\mathrm{M}$ (marasmus) & $1-3$ & \\
\hline Score for MK (marasmic & & \\
\hline kwashiorkor) & $4-7$ & \\
\hline Score for K (kwashiorkor) & $8+$ & \\
\hline
\end{tabular}

Table 2. Calculation of weight for given height in children (Harvard standard).

\begin{tabular}{ccc}
\hline & Boy & Girl \\
\hline Weight-height relation & $\begin{array}{c}W=0.24 H-8.28 \\
r=0.995\end{array}$ & $\begin{array}{c}W=0.24 H-8.13 \\
r=0.997\end{array}$ \\
Correlation coefficient & \begin{tabular}{l}
$r=0.13$ \\
\hline
\end{tabular}
\end{tabular}

independent of age. We have seen that by using the Harvard standard, the weight for a given height is linear when the height is between $50-95 \mathrm{~cm}$. The equation to calculate the expected weight $(W)$ for given height $(H)$ is shown in Table 2 . The equation for boys is $W=0.24 H-8.28$, and for girls $W=0.24 H-8.13$. The correlation coefficients for the above two equations are above 0.9 .

Feeding and clinical history

In rural areas of Northern Thailand, breast milk is the primary source of food during the first year of life. Colostrum is ordinarily discarded because of the colour and the belief that it will cause diarrhea or fever. In general, the weaning period is about 18 months, with a range of between 7 and 30 months. Ground rice and mashed bananas are commonly used for feeding the children during their first year Vol. 26, No. 3, 1980 
of life. Meat, eggs, vegetables and other fruits are not customarily given during the first year. Dairy products are neither available in adequate quantities nor sufficiently appreciated. Sweetened, condensed milk is the only item commonly consumed when breast milk, for any reason, is not adequate or available.

Selected aspects of the clinical history of patients with PCM are shown in Table 3. It is shown that diarrhea in children with PCM was the most common symptom prior to admission. Fever was the second most common symptom reported by the parent. A history of cough was found among $62 \%$ of these PCM cases; but of this number only $58 \%$ had X-ray evidence of pneumonia. At the same time, $25 \%$ who had positive chest X-rays had no history of cough. Edema was seen in $56 \%$ of total cases. It is interesting that $7 \%$ of children with marasmus had a history of edema some time prior to admission. No child was brought to the hospital because its parents felt that it was malnourished.

\section{Clinical and laboratory findings}

The clinical data are given in Table 4. It is shown that marasmic children are somewhat younger, smaller, and lighter than the others. The average weight was $5.7 \mathrm{~kg}$ and only $49 \%$ of expected weight for age, calculated from the Harvard standard. Children in the kwashiorkor group were the oldest, and also highest in body weight, due mostly to an expansion of extracellular fluid. The marasmic kwashiorkor group was intermediate in age and body weight. The weight for height of the three groups ranged from 69 to $77 \%$.

Table 3. Clinical history of PCM.

\begin{tabular}{llccc}
\hline \multicolumn{2}{c}{ History } & M & MK & K \\
\hline Diarrhea & $(\%)$ & 67 & 78 & 81 \\
Fever & $(\%)$ & 69 & 71 & 69 \\
Edema & $(\%)$ & 7 & 78 & 87 \\
Cough & $(\%)$ & 62 & 62 & 56 \\
\hline
\end{tabular}

Table 4. Clinical data.

\begin{tabular}{lrrr}
\hline & \multicolumn{1}{c}{ M } & \multicolumn{1}{c}{ MK } & \multicolumn{1}{c}{ K } \\
\hline Age (Mo.) & $21.6 \pm 1.3$ & $27.0 \pm 1.3$ & $29.1 \pm 1.9$ \\
Weight (kg) & $5.7 \pm 0.2$ & $6.8 \pm 0.2$ & $7.7 \pm 0.2$ \\
$\%$ Weight for age & $49.4 \pm 1.0$ & $53.4 \pm 1.7$ & $58.7 \pm 1.3$ \\
Height (cm) & $68.8 \pm 0.8$ & $70.7 \pm 0.9$ & $76.5 \pm 1.0$ \\
$\%$ Height for age & $82.5 \pm 0.8$ & $84.6 \pm 0.7$ & $85.5 \pm 0.8$ \\
$\%$ Weight for height & $70.3 \pm 1.2$ & $69.0 \pm 1.0$ & $75.5 \pm 1.2$ \\
\hline
\end{tabular}


Vitamin status in protein calorie malnutrition is shown in Table 5. There is a high incidence of vitamin A deficiency in Thai children with severe protein calorie malnutrition, as evidenced by ocular pathology and low serum vitamin A levels. Clinical evidence of thiamine deficiency (such as hoarseness, peripheral neuropathy, and/or congestive heart failure) is rare, whereas the clinical signs of riboflavin deficiency (as shown by glossitis, nasolabial seborrhea, and angular stomatitis) are common. But the clinical signs of these two vitamin deficiencies are deceptive because there is little correlation between the clinical signs and the biochemical findings (25). Vitamin D deficiency was not common among the PCM children seen at this Center.

Regarding the infections associated with PCM (Table 6), it has already been noted that diarrhea is common. Stool cultures were found to be positive in only one third of these children; pathogenic E. coli was the most common pathogen grown from the stool. Pneumonia diagnosed by X-ray was also common among all types of PCM. Sepsis was a serious form of infection among these children. Gramnegative bacteria were frequently grown from the blood, including Pseudomonas, E. coli, Proteus, and Bacteroides. It is very striking to note that sepsis confirmed by positive blood culture was found among $75 \%$ of those patients who died. The proper diagnosis of infection in PCM children is crucial to their proper care. Besides a general physical examination, one should consider a routine chest X-ray,

Table 5. Vitamin status in PCM children.

\begin{tabular}{|c|c|c|c|c|}
\hline \multicolumn{2}{|c|}{$\begin{array}{l}\text { Vitamin } \\
\text { deficiency }\end{array}$} & \multirow{2}{*}{$\begin{array}{c}\mathrm{M} \\
42.65\end{array}$} & \multirow{2}{*}{$\begin{array}{l}\text { MK } \\
51.00\end{array}$} & \multirow{2}{*}{$\begin{array}{c}\mathrm{K} \\
52.44\end{array}$} \\
\hline A & $(\%)$ & & & \\
\hline & $(\%)$ & 1.47 & 2.00 & 6.10 \\
\hline & $(\%)$ & 11.76 & 24.00 & 40.24 \\
\hline D & $(\%)$ & 19.12 & 12.00 & 6.10 \\
\hline
\end{tabular}

Table 6. Infection in PCM.

\begin{tabular}{llrll}
\hline \multicolumn{1}{c}{ Types } & & M & MK & K \\
\hline Pneumonia & $(\%)$ & 54.41 & 45.00 & 29.27 \\
G.U. infection & $(\%)$ & 29.41 & 45.95 & 24.39 \\
Otitis media & $(\%)$ & 22.06 & 31.00 & 23.17 \\
Stool pathogen & $(\%)$ & 26.47 & 38.00 & 45.12 \\
Skin infection & $(\%)$ & 10.29 & 10.00 & 31.71 \\
Sepsis & $(\%)$ & 5.88 & 14.00 & 28.05 \\
\hline
\end{tabular}

${ }^{a}$ G.U.: genito urinary tract infection.

Vol. 26, No. 3, 1980 
white blood count and differential count, urinalysis and culture, stool culture, blood and other indicated cultures. In the case of pneumonia, we have found that $64 \%$ of our children with negative physical findings had pneumonia diagnosed by $\mathrm{X}$-ray. We found that sepsis was the most serious and life-threatening complication of infection. Therefore, one should suspect sepsis when the following are noted:

a) Hypothermia with hypotension (temperature below $36^{\circ} \mathrm{C}$, blood pressure below $60 / 40 \mathrm{mmHg}$ ).

b) Shift to the left with a normal or elevated white cell count.

c) Petechia: This can be especially noticed when pressure is applied to the skin, such as when rubbing the skin during a bath or when applying ECG electrodes to the chest wall.

d) Hyponatremia: Serum sodium below $115 \mathrm{mEq} /$ liter.

The above findings correlated with the clinical appraisal of the patient should alert one to the possibility of sepsis.

\section{Hematological and biochemical findings}

It was shown in Table 7 that anemia is mild. Hemoglobin values averaged about $10 \mathrm{~g} \%$ on admission, although after 1 week of treatment the hemoglobin values of $50 \%$ of patients dropped to below $10 \mathrm{~g} \%$. The plasma protein values for the three main classes of PCM were typical of those reported previously (26-28). Serum albumin levels were markedly depressed in the kwashiorkor group. The transferrin content was measured by total iron-binding capacity (T.I.B.C.) and was below the normal level in all classes of children, but markedly reduced in kwashiorkor. Plasma levels remained unchanged in all three groups, meaning that the transferrin of children with kwashiorkor is more highly saturated. The serum folate level showed a slight decline but was above the level associated with true deficiency. Megaloblastic anemia was rare. The serum cholesterol level was low, being most markedly reduced in the kwashiorkor group. The average serum vitamin A content was low, with about $54 \%$ of children showing frank signs of vitamin A

Table 7. Biochemical data.

\begin{tabular}{lccc}
\hline & M & MK & K \\
\hline Hgb $(\mathrm{g} \%)$ & $10.5 \pm 0.3$ & $10.5 \pm 0.4$ & $10.0 \pm 0.3$ \\
Albumin $(\mathrm{g} \%)$ & $3.0 \pm 0.1$ & $2.0 \pm 0.1$ & $1.5 \pm 0.1$ \\
IgG $(\mathrm{g} \%)$ & $1.3 \pm 0.1$ & $1.4 \pm 0.1$ & $1.0 \pm 0.3$ \\
T.I.B.C. $(\mu \mathrm{g} \%)^{\mathrm{a}}$ & $244.8 \pm 21.0$ & $142.1 \pm 11.0$ & $125.0 \pm 16.0$ \\
R.B.P. $(\mu \mathrm{g} / \mathrm{ml})^{\mathrm{b}}$ & $23.3 \pm 2.6$ & $21.5 \pm 3.0$ & $19.7 \pm 0.6$ \\
Vit A $(\mu \mathrm{g} \%)$ & $29.0 \pm 3.1$ & $25.3 \pm 5.0$ & $17.1 \pm 2.0$ \\
Folic acid $(\mathrm{ng} / \mathrm{ml})$ & $9.4 \pm 1.2$ & $7.5 \pm 0.9$ & $5.1 \pm 0.6$ \\
Cholesterol $(\mathrm{mg} \%)$ & $109.0 \pm 6.0$ & $82.0 \pm 5.0$ & $77.0 \pm 6.0$ \\
\hline
\end{tabular}

a T.I.B.C.: total iron binding capacity. ${ }^{\mathrm{b}}$ R.B.P.: retinol-binding protein. 
deficiency. Retinol-binding protein (R.B.P.) and serum vitamin A levels were decreased. Vitamin A fell from a normal level of about 50 to $29 \mu \mathrm{g} / \mathrm{ml}$ in the marasmic children and to $17 \mu \mathrm{g} / \mathrm{ml}$ in the kwashiorkor group.

McFarlane and his colleagues $(28,29)$ have suggested that serum transferrin may be a better indicator of protein deficiency than albumin in children with PCM. We have looked into this problem and found that there is a linear correlation between serum albumin and transferrin, regardless of the type of malnutrition, as shown in Fig. 2. The correlation coefficient is equal to 0.9. Therefore, serum albumin is as good an index of nutritional status as serum transferrin.

\section{Treatment of protein calorie malnutrition}

There are four essential principles in the treatment of protein calorie malnutrition:

1. Fluid and electrolyte therapy;

2. Therapy for infection;

3. Therapy for vitamin deficiencies;

4. Dietary therapy (to which the major emphasis is given in this paper).

Fluid and electrolyte therapy. Children with protein calorie malnutrition admitted to our metabolic unit in Chiang Mai showed normal or low sodium, low potassium, and often low magnesium levels in the serum. Low serum potassium was a common finding among our kwashiorkor children, especially when diarrhea was present. The initial supplement of potassium intravenously or orally in severe potassium depletion should be about $7-8 \mathrm{mEq} / \mathrm{kg} / \mathrm{day}$, with maintenance doses of 5 $\mathrm{mEq} / \mathrm{kg} /$ day orally thereafter.

Opinions differ on the amount of sodium needed for the treatment of severe PCM with diarrhea. The high dosage of $6 \mathrm{mEq} / \mathrm{kg} /$ day has been recommended by

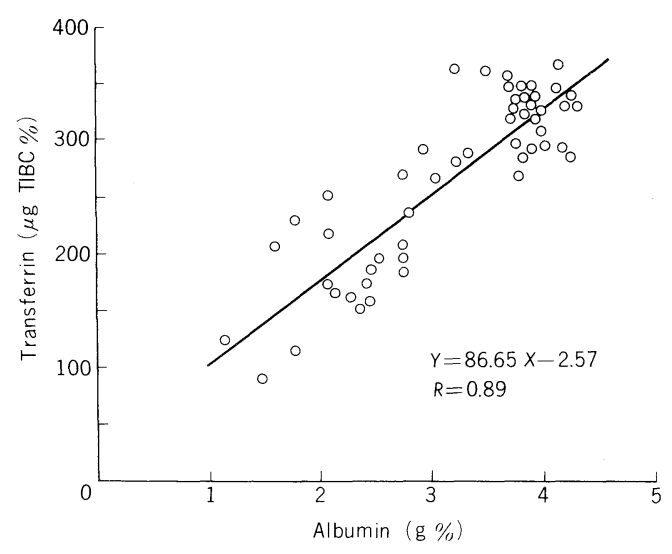

Fig. 2. Correlation of albumin and transferrin. 
Dean and Swanne (30). Low sodium diet $1 \mathrm{mEq} / \mathrm{kg} /$ day was used successfully by Wharton (31). He found that, by this method, cardiac failure associated with PCM in his children was almost eradicated, even among these with low hemoglobin levels. We daily used $2.7 \mathrm{mEq}$ of sodium in the total diet per kilogram of body weight among PCM children with diarrhea. With this regimen of sodium intake, cardiac failure during the initial course of treatment has not been a problem in our patients. The amount of low sodium intake should be carefully controlled among kwashiorkor children with severe edema. This type of child should receive only the amount of sodium available in the milk formula, even when using a diluted milk formula. One might argue about the usefulness of intravenous fluid and electrolyte therapy, and prefer to use intragastric fluid administration (32). But we are convinced that the administration of fluid and electrolytes, especially during the first $24 \mathrm{hr}$, is very advantageous for the improvement of children suffering from severe PCM with associated diarrhea.

Therapy for infection. The type and dosage of antibiotics used for the treatment of infection in severe PCM depend on the site and severity of infection (33). Prophylactic antibiotics are not used. When sepsis is suspected, one should initiate aggressive therapy to cover Gram-positive and Gram-negative bacteria, particularly Pseudomonas.

Vitamin therapy. The clinical signs of PCM relative to vitamin deficiency diseases are deceptive. The manifestation of protein deficiency per se in the mouth, skin etc. may overshadow, alter or substitute for the classical manifestation of Bcomplex vitamin deficiencies. Our findings show that children with PCM have depressed stores of both water-soluble and fat-soluble vitamins (25). All children should be supplemented with all vitamins, not only to resaturate the shrunken tissue but also to provide adequate amounts for the proper functioning of new tissue generated during growth. The amount of vitamin required during the initial treatment, as well as during maintenance therapy, is shown in Table 8. An additional 100,000 I.U. of vitamin $\mathrm{A}$ is added when there is a sign of vitamin A deficiency.

Dietary therapy. The optimum requirement of protein and calories for the treatment of severe protein calorie malnutrition remains controversial, despite wide experience with various regimens in many countries in the world. Several investigators have emphasized the importance of high protein intake (34-37), whereas other investigators have stressed the importance of calories (38-41). It is obvious that adequate quantities of both protein and calories are necessary to promote optimum recovery in severe PCM children. The general hypothesis which has emerged from a variety of studies is that, once the protein minimum is met for maximum growth in these sick children, actual growth is dependent on the calorie intake. Periera et al. in 1965 (38) found that feeding 3, 4, and $5 \mathrm{~g}$ protein $/ \mathrm{kg} /$ day made no difference to the rate of recovery if $150 \mathrm{Cal} / \mathrm{kg} /$ day were supplied. Graham et al., 1963(39) showed that $175 \mathrm{Cal} / \mathrm{kg} /$ day was necessary to establish an adequate rate of weight gain in severely malnourished children fed $3 \mathrm{~g}$ of 
Table 8. Vitamin supplementation.

\begin{tabular}{llcc}
\hline \multicolumn{1}{c}{ Vitamin } & $\begin{array}{c}\text { Daily initial therapy } \\
\text { i.m. or i.v. for } \\
\text { 3 days beginning } \\
\text { on day 2 }\end{array}$ & $\begin{array}{c}\text { Daily maintenance } \\
\text { therapy from the } \\
\text { fifth day until } \\
\text { the end of week } 10\end{array}$ \\
\hline Thiamine & $(\mathrm{mg})$ & 5.0 & 0.6 \\
Riboflavin & $(\mathrm{mg})$ & 5.0 & 1.0 \\
Pyridoxine & $(\mathrm{mg})$ & 2.5 & 1.0 \\
Nicotinamide $(\mathrm{mg})$ & 37.5 & 11.0 \\
Pantothenate & $(\mathrm{mg})$ & 5.0 & 5.0 \\
Ascorbic acid $(\mathrm{mg})$ & 200 & 30.0 \\
Folic acid & $(\mathrm{mg})$ & 1.5 & 0.1 \\
Vitamin B & $(\mu \mathrm{g})$ & 7.5 & 5.0 \\
Vitamin A & $(\mathrm{I} . \mathrm{U})$. & 5,000 & 2,500 \\
Vitamin D & $(\mathrm{I} . \mathrm{U})$. & 400 & 400 \\
Vitamin E & $(\mathrm{I} . \mathrm{U})$. & 300 & 50 \\
Vitamin K & $(\mu \mathrm{g})$ & & 100 \\
\hline
\end{tabular}

protein $/ \mathrm{kg} /$ day. Since he also found that less severely malnourished children could recover on $2 \mathrm{~g}$ of protein $/ \mathrm{kg} / \mathrm{day}$, it is likely that the requirement of protein is directly proportional to the severity of the disease, beginning at $1 \mathrm{~g} / \mathrm{kg} / \mathrm{day}$ for normal children and rising to $3 \mathrm{~g} / \mathrm{kg} /$ day for severely malnourished children, provided that optimum amounts of calories are fed. Grimble and Whitehead in 1970 (42) reported that with protein intake in the range of 0.9 to $4.7 \mathrm{~g} / \mathrm{kg} / \mathrm{day}$, at a calorie intake of about $140 \mathrm{Cal} / \mathrm{kg} / \mathrm{day}, 4.7 \mathrm{~g}$ of protein $/ \mathrm{kg} /$ day was required to give a maximal rate of growth and serum albumin regeneration. At the suboptimum calorie intake, a higher proportion of protein appeared to be useful. On the other hand, Rutishauser and McCance in 1968 (40) demonstrated that on a diet containing $4 \mathrm{~g}$ of protein $/ \mathrm{kg} /$ day, the weight change in malnourished children was proportional to calories in the range of $120-250 \mathrm{Cal} / \mathrm{kg} / \mathrm{day}$. Gopalan et al., 1974 (43) showed that at $200 \mathrm{Cal} / \mathrm{kg} / \mathrm{day}$, protein had no effect in the range of 3.5 to $6 \mathrm{~g} / \mathrm{kg} / \mathrm{day}$, although at suboptimal calorie intake protein did stimulate growth when fed at $6 \mathrm{~g} / \mathrm{kg} /$ day.

To compare the effects on growth and serum protein regeneration of an ad libitum diet using solid food together with a milk formula and a milk-based formula containing differing amounts of calories and protein, 176 severely malnourished children were included in the study. The formula was given by tube feeding when indicated. Corn oil and dextrose were added to the formula to supplement calories to the required level. Essential vitamins and minerals were also added to our regimen of treatment as shown in Tables 8 and 9. The use of the milkbased formula among our children with severe PCM did not appear to cause the prolonged diarrhea observed by others (44-46).

Vol. 26, No. 3, 1980 
Table 9. Mineral supplementation. ${ }^{\mathrm{a}}$

\begin{tabular}{ll}
\hline Mineral & $\begin{array}{c}\text { Dose } \\
(\mathrm{mEq} / \mathrm{kg} / \text { day })\end{array}$ \\
\hline $\mathrm{Na}$ & 2.7 \\
$\mathrm{~K}$ & 5.0 \\
$\mathrm{Ca}$ & 7.3 \\
$\mathrm{Mg}$ & 1.4 \\
$\mathrm{Zn}$ & 0.014 \\
$\mathrm{Mn}$ & 0.018 \\
$\mathrm{Cu}$ & 0.0028 \\
$\mathrm{I}$ & 0.00008 \\
$\mathrm{~F}$ & 0.006 \\
$\mathrm{Al}$ & 0.070 \\
$\mathrm{Mo}$ & 0.001 \\
$\mathrm{Cr}$ & 0.366 \\
$\mathrm{Se}$ & 0.003 \\
\hline
\end{tabular}

a Mineral content of formula and supplementary trace minerals.

The experimental design is shown in Table 10. One group was fed on a milkbased formula supplemented with solid food (rice, pork, vegetables, and fruit). Six groups were fed specified levels of protein and calories by formula for a 10 -week period. The lowest intake fed was that required to maintain normal growth and development in healthy children of the same age, namely $1 \mathrm{~g}$ protein and 100 $\mathrm{Cal} / \mathrm{kg} /$ day (Arroyave, 1969) (47). The most nutritious formula fed contained $4 \mathrm{~g}$ protein and $175 \mathrm{Cal} / \mathrm{kg} /$ day. The other formulae consisted of permutations of these two values. The various dietary compositions were obtained by adding corn oil and dextrose to full cream milk powder. The ratio of total carbohydrate to fat calories was kept constant at 0.85 . The calorific density of the formula was kept essentially constant at $20 \pm 5 \mathrm{Cal} / \mathrm{oz}$ by appropriate dilutions. The children received adequate minerals and vitamins(33). The rate of growth was measured, and the serum albumin was evaluated at the same intervals by the biuret technique. Children were discharged after 12 weeks. Fifty percent thereof have since been followed up at yearly intervals.

In the group given ad libitum feeding (Group VII), during the first week protein intake gradually increased from 1.6 to $5.6 \mathrm{~g} / \mathrm{kg}$ /day and the calorie intake from 25 to $120 \mathrm{Cal} / \mathrm{kg} /$ day. In the second week, the protein intake rose further from 5 to $7 \mathrm{~g} / \mathrm{kg} /$ day and calories from 120 to $180 \mathrm{Cal} / \mathrm{kg} /$ day. The total intake then remained relatively constant for an additional 2 weeks, and thereafter began to decline gradually, reaching values of $5 \mathrm{~g}$ protein and $120 \mathrm{Cal} / \mathrm{kg} /$ day at 10 weeks. Children with marasmus appear to consume somewhat more food than average during the first 2 weeks and somewhat less than average during the last 4 weeks of the test period. 
Table 10. Experimental design of protein calorie study.

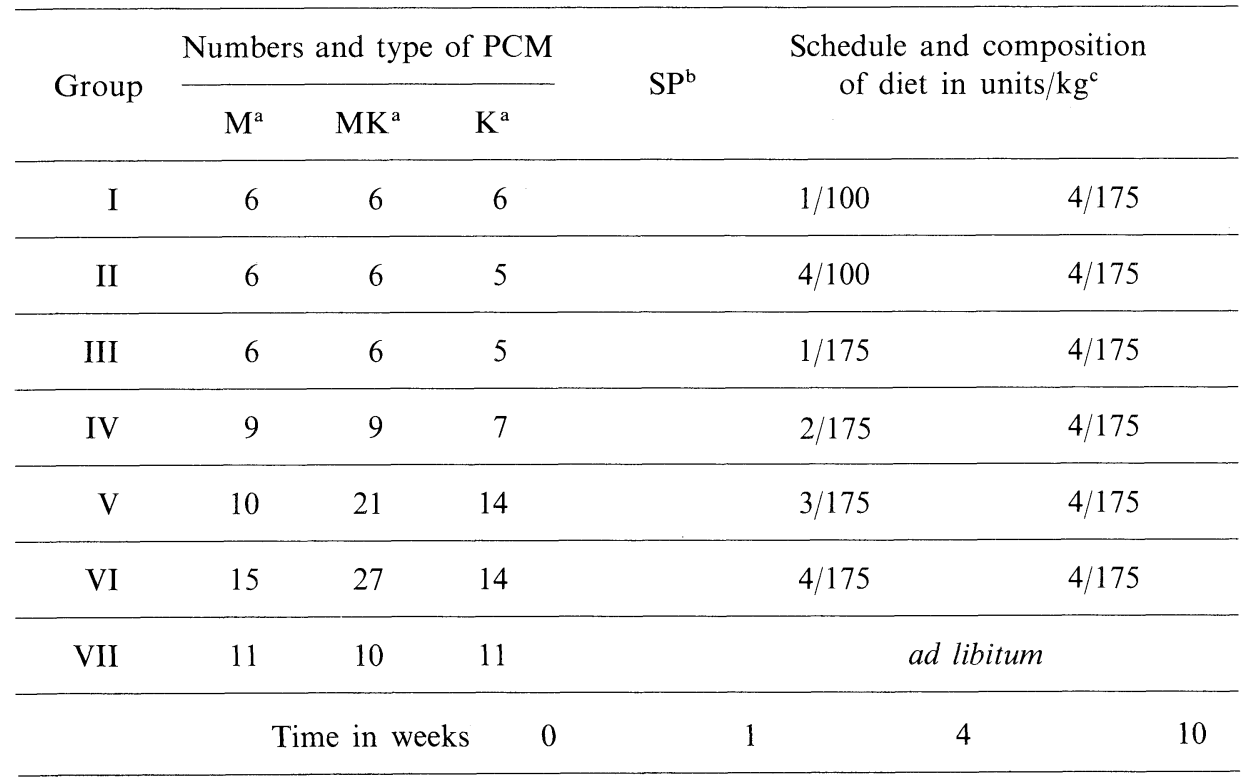

${ }^{a} \mathrm{M}$, marasmus; MK, marasmic kwashiorkor; $\mathrm{K}$, kwashiorkor. ${ }^{\mathrm{b}}$ SP: stabilization period during which all subjects were fed $1 \mathrm{~g}$ protein $/ \mathrm{kg}$ and increasing calories from $25-100 / \mathrm{kg}$ for 1 week. ${ }^{\mathrm{c}}$ Numbers indicate $\mathrm{g}$ protein/Cal per $\mathrm{kg}$ per day.

The change of the percentage of body weight during treatment among children with $\mathrm{M}, \mathrm{MK}$, and $\mathrm{K}$ in Groups I to VII is shown in Fig. 3. There was no significant change in the percentile body weight of marasmic children in Groups I and II during the first 3 weeks. Groups IV, V, and VI, which received $2 \mathrm{~g}, 3 \mathrm{~g}$, and $4 \mathrm{~g}$ of protein with $175 \mathrm{Cal} / \mathrm{kg} / \mathrm{day}$, and Group VII with ad libitum feeding, all showed significant changes over the first 3 weeks. Groups I, II, and III showed catch-up growth on $4 \mathrm{~g}$ protein and $175 \mathrm{Cal} / \mathrm{kg} /$ day between day 29 and 50 .

Among children with marasmic kwashiorkor it was shown that during the first 3-week period Groups I, II, and III showed no significant growth, whereas Groups IV, V, VI, and VII grew. Groups I, II, and III showed catch-up growth between day 29 and 50, and at day 70 there was no significant difference in the total growth increment between all the groups.

Children with kwashiorkor in Groups I, II, III, and IV did not grow during the first 3 weeks, and showed catch-up growth during days 29 to 50 . Groups V and VI, which received 3 and $4 \mathrm{~g}$ protein with $175 \mathrm{Cal} / \mathrm{kg} /$ day, and Group VII which received ad libitum diet, grew well. At 70 days all children had essentially the same weight for age.

Weight-for-height changes among 176 children with marasmus, marasmic kwashiorkor, and kwashiorkor during treatment with various amount of proteins Vol. 26, No. 3, 1980 


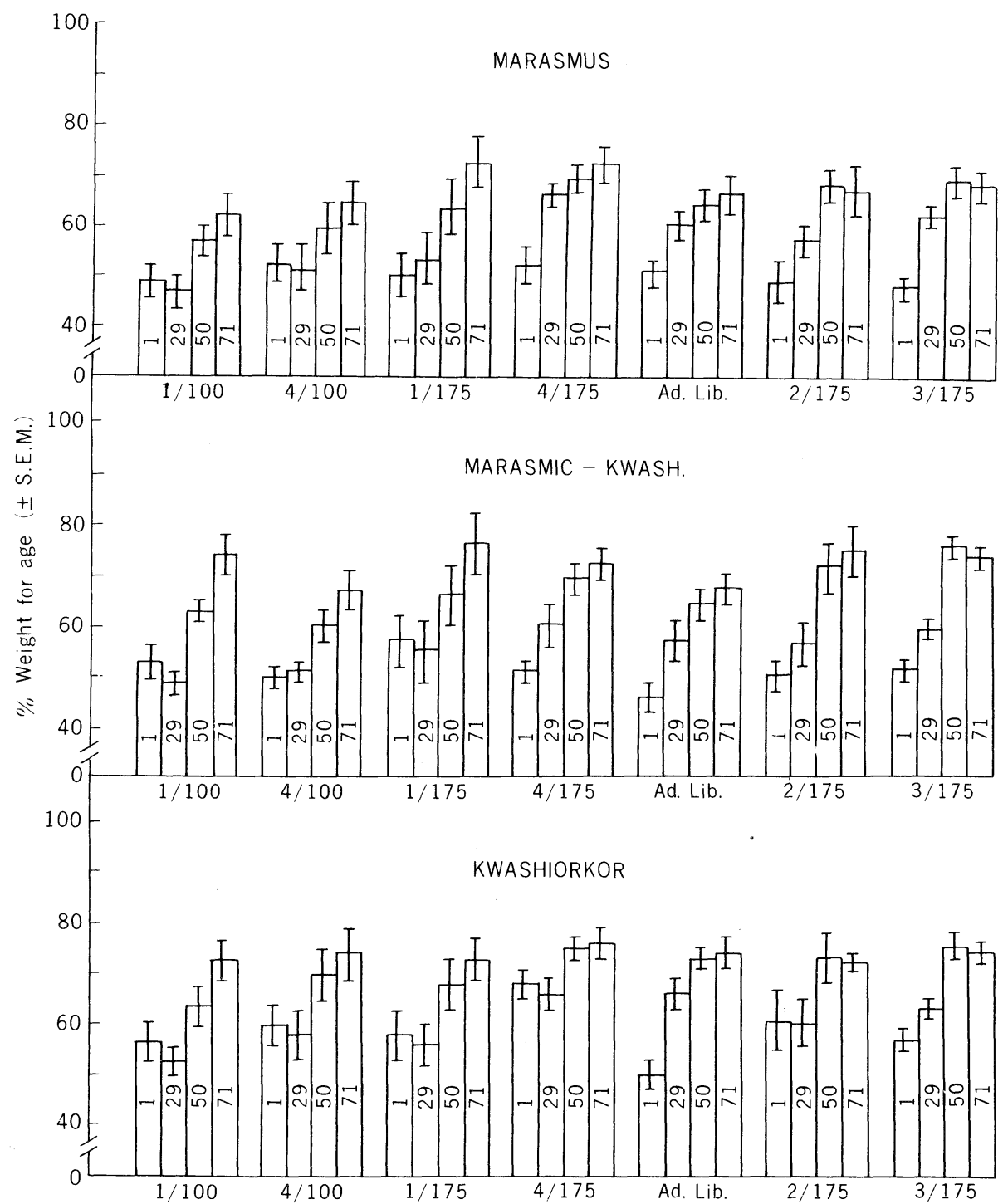

Fig. 3. Percent weight-for-age changes in PCM after treatment. The number in the open block means number of days after admission to the hospital. Numbers under the baseline indicate composition of diet in units $/ \mathrm{kg}$ for the first 4 weeks ( $c f$. Table $10)$.

and calories intake are shown in Fig. 4. They reflect closely the data presented in Fig. 3 describing changes of weight for age. In all cases there were no significant changes in weight for height of PCM children in Groups I, II, and III during the first 3 weeks. When comparing the results of the weight for height using diet 


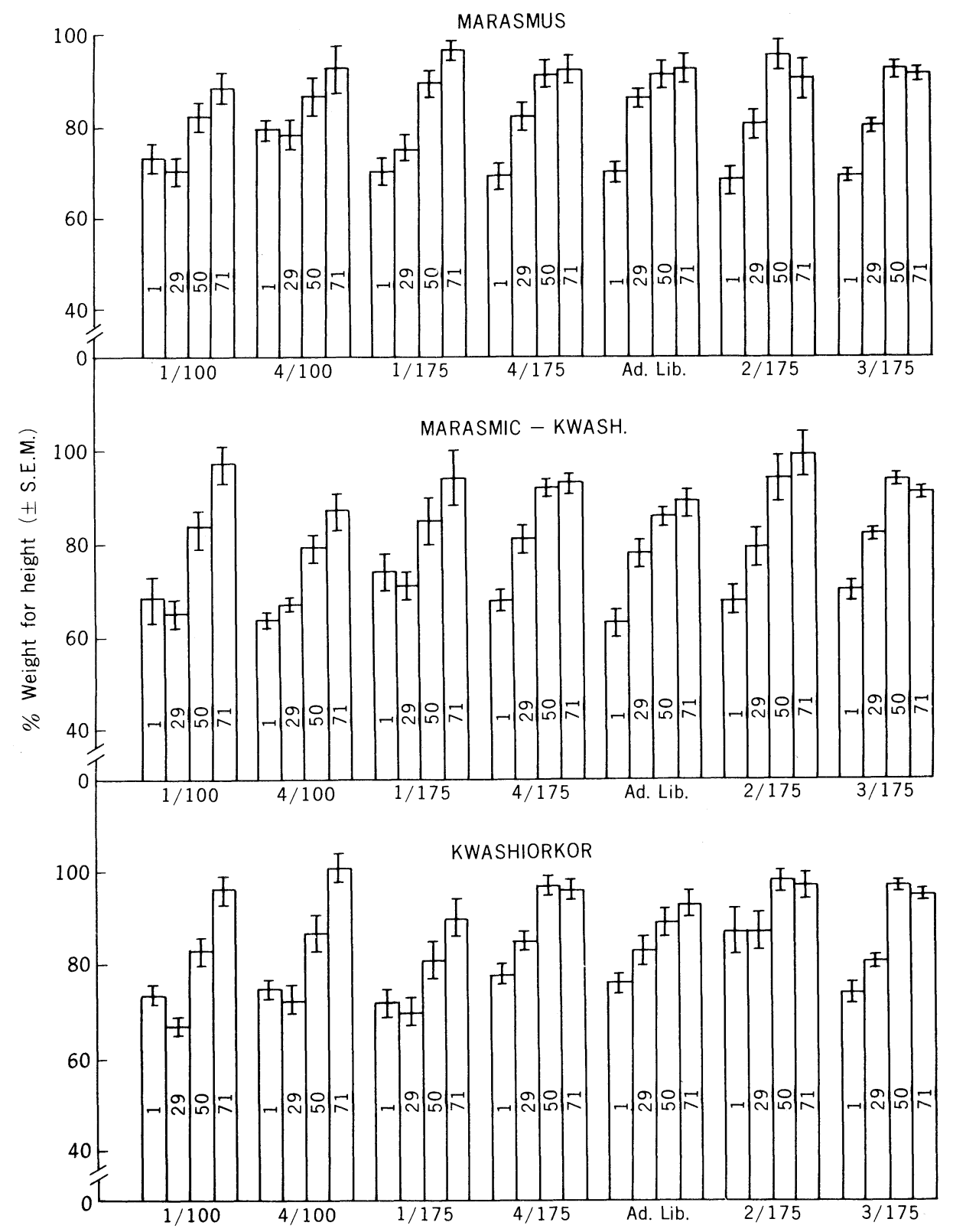

Fig. 4. Percent weight-for-height change in PCM after treatment. See legend of Fig. 3.

IV-VII, it is shown that a diet which supplies $2 \mathrm{~g}$ protein with $175 \mathrm{Cal} / \mathrm{kg} /$ day is adequate to promote growth in children with marasmus and marasmic kwashiorkor, but not in children with kwashiorkor. Diets which supply 3 and $4 \mathrm{~g}$ protein Vol. 26, No. 3, 1980 
with $175 \mathrm{Cal} / \mathrm{kg} /$ day and ad libitum feeding caused significant changes in weight for height among all children with different types of protein calorie malnutrition.

The changes in serum albumin as a function of treatment for children with marasmus, marasmic kwashiorkor and kwashiorkor are shown in Fig. 5. As expected, the marasmic children showed less depression of serum albumin levels on admission than did children with marasmic kwashiorkor and kwashiorkor. All patients fed $1 \mathrm{~g}$ protein $/ \mathrm{kg} /$ day regardless of calorie intake showed no changes in albumin concentration over the first 3 weeks. Diet with $2 \mathrm{~g}$ protein and 175 $\mathrm{Cal} / \mathrm{kg} /$ day normalized the serum albumin concentration among children with marasmus, but not among children with marasmic kwashiorkor and kwashiorkor.

Diets which contain either 3 or $4 \mathrm{~g}$ protein with $175 \mathrm{Cal}$ are equally good for the stimulation of albumin regeneration, and the higher protein intake in Group VII did not accelerate the rate of regeneration. It is of interest that a diet containing $4 \mathrm{~g}$ protein, but suboptimal calories (100 Cal $/ \mathrm{kg} /$ day), was sufficient to bring serum albumin to a normal concentration, but not to stimulate the growth of children with protein calorie malnutrition.

After the 10-week formula diet, all children were put on an ad libitum diet, consisting of solid food and milk formula, which provided $175 \mathrm{Cal}$ and $4 \mathrm{~g}$ protein $/ \mathrm{kg} / \mathrm{day}$, if the child consumed all of the diet prepared. We found that the food intake gradually dropped to about $120 \mathrm{Cal} / \mathrm{kg} /$ day with $3 \mathrm{~g}$ protein $/ \mathrm{kg} / \mathrm{day}$. It appears that both the protein and calorie requirement gradually falls to physiologic levels as the child attains full recovery.

Sixty-five percent of all our patients have been followed up in their villages annually since discharge. Regardless of the amount of protein and calorie intake in hospital during the diet study-period, we have found that their growth pattern is good; and that the percentage of the weight for age, weight for height, and height for age are similar to the values obtained at the end of hospitalization, during which children in all groups had shown good catch-up growth. We have noticed that the height for age in marasmus is only $65 \%$ of normal, which is significantly lower than found with the kwashiorkor group. The latter has a height for age of $77 \%$ of normal, even though the weights for age do not greatly differ among the various groups of children. This seems to indicate that marasmus children are relatively stunted when compared with children who have had marasmic kwashiorkor or kwashiorkor.

It appears from our own and other studies that the protein requirement for recovery from severe calorie malnutrition is in the vicinity of $3 \mathrm{~g} / \mathrm{kg} / \mathrm{day}$. At this level of protein intake, the growth rate is proportional to calorie intake in the range of 120 to $250 \mathrm{Cal} / \mathrm{kg} /$ day. Our study indicated that $175 \mathrm{Cal} / \mathrm{kg} /$ day is sufficient to promote adequate growth. 


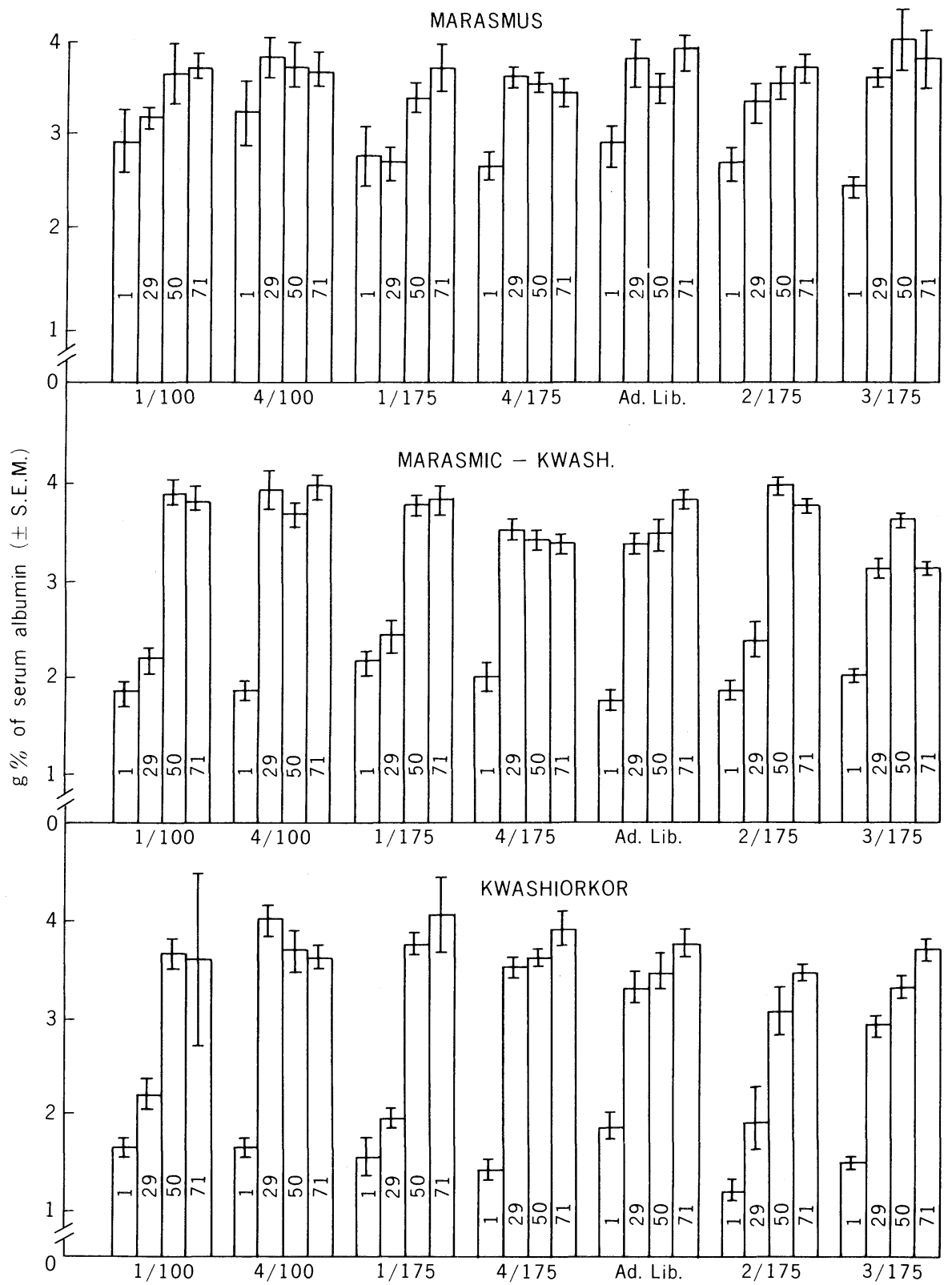

Fig. 5. Serum albumin $(\%)$ changes in PCM. See legend of Fig. 3. 


\section{SUMMARY}

We have investigated the pathophysiology and optimum treatment of PCM in Northern Thai children over the past 10 years and have developed what we consider to be an improved scoring system for the diagnosis of the three major forms of severe protein calorie malnutrition, namely: marasmus, marasmic kwashiorkor, and kwashiorkor. We feel that it gives a more definitive classification of these subgroups of PCM than any other system. It takes into account anthropometric and laboratory parameters, as well as clinical ones, and permits hospitals and metabolic units in various parts of the world to make better comparisons of their results.

Various aspects of the pathophysiology of PCM have been studied, including hematopoietic, endocrine, and metabolic aspects. We have developed a plan of therapy which has reduced mortality to $6-7 \%$. In support of our plan of treatment, we have presented the clinical and biochemical data, and have demonstrated the protein and calorie requirements for the optimum treatment of severe protein calorie malnutrition.

The distribution of the three forms of protein calorie malnutrition clearly differs widely in affected countries throughout the world. In some, marasmus is more prevalent; in others, kwashiorkor. Investigators not familiar with the global distribution of the types of the disease may be regarding their particular population of children in a special way.

This work was supported in part by National Institute of Health Grant AM 11044 and the Royal Thai Government.

\section{REFERENCES}

1) WHO Sixth Report Joint FAO/WHO Expert Committee on Nutrition (1962): WHO Tech. Rep. Ser., No. 245.

2) McCance, R. A., and Widdowson, E. M. (1966): Lancet, i, 709.

3) Gopalan, C. (1967): Kwashiorkor and marasmus: Evaluation and distinguishing features, in Calorie Deficiencies and Protein Deficiencies, ed. by McCance, R. A., and Widdowson, L. M., J and A Churchill, p. 47.

4) Waterlow, J. C., and Stephen, J. M. L. (1966): Br. J. Nutr., 20, 461.

5) Pimstone, B. L., Wittmann, W., Hansen, J. D., and Murray, P. (1966): Lancet, ii, 779.

6) Möckenberg, F., Donoso, G., Oxman, S., Pak, N., and Meneghello, J. (1963): Pediatrics, 31, 58.

7) Rao, K. S. J. (1974): Lancet, i, 709.

8) Whitehead, R. G., Coward, W. A., Lunn, P. G., and Ingrid Rutishouser (1976): Proceedings in Protein Energy Malnutrition, Clunbury Press.

9) Olson, R. E. (1957): J. Am. Med. Assoc., 164, 1758.

10) Alleyne, G. A. O., and Young, V. H. (1967): Clin. Sci., 33, 189.

11) Rao, K. S. J., Srikantia, S. G., and Gopalan, C. (1968): Arch. Dis. Childh., 43, 365.

12) Mulroy, P. J. (1974): in Duncan's Diseases of Metabolism, ed. by Bondy, P. K. and 
Rosenberg, L. E., W. B. Saunders, Philadelphia, p. 1431.

13) McLaren, D. S. (1966): Lancet, 2, 85.

14) Shakir, A., Dermachi, M., and El-Milti, N. (1972): Lancet, ii, 143.

15) Thanangkul, O., Suskind, R., and Olson, R. E. (1972): Infections in PCM, 9th Proc. Int. Cong. Nutr.

16) Gomez, F., and Frank, S. (1955): Adv. Pediatr., 7, 131.

17) Waterlow, J. C. (1972): Br. Med. J., 2, 566.

18) Waterlow, J. C. (1973): Lancet, ii, 87.

19) Waterlow, J. C. (1974): Br. Med. J., 4, 88

20) Stewart, H. C., and Stephenson, S. S. (1959): Text book of Pediatrics, W. Nelson, Philadelphia, p. 12.

21) Habicht, J. P., Martorell, R., Yarbrough, C., Malina, R. M., and Klein, R. E. (1974): Lancet, i, 611.

22) Van Wieringen, J. C. (1972): Secular changes of growth: 1964-66: Height and weight surveys in the Netherlands in historical perspective. Netherland Institute for Preventive Medicine T.N.O., Leiden.

23) Lancet, ii, 302, 1970 (annotation).

24) McLaren, D. S., Pellett, P. L., and Read, W. W. C. (1967): Lancet, i, 538.

25) Thanangkul, O. (1974): Water-soluble vitamins in protein calorie malnutrition, in Protein Calorie Malnutrition, ed. by Olson, R. E., Academic Press, New York, p. 149.

26) Anita, A. U., McFarlane, H., and Soothill, J. F. (1968): Arch. Dis. Childh., 43, 459.

27) Scrimshaw, N., Behar, M., Arroyave, G., Tijade, C., and Vitreri, I. (1975): J. Am. Med. Assoc., 194, 555.

28) McFarlane, H., Adcock, K. I., Cooke, A., Ogheide, M. I., Adeshina, H., Taylor, G. O., Reddy, S., Gurney, J. M., and Mordie, J. A. (1969): Lancet, i, 392.

29) McFarlane, H., Reddy, S., Adcock, K. J., Adeshina, H., Cooke, A. R., and Akena, J. (1970): Br. Med. J., 4, 268.

30) Dean, R. F. A., and Swanne, J. (1963): Abbreviation schedule of treatment of severe kwashiorkor. J. Trop. Pediatr., 8, 97.

31) Wharton, B. A. (1967): Kwashiorkor initial treatment, in Calorie Deficiencies and Protein Deficiencies, ed. by McCance, R. A. and Widdowson, E. M., Churchill, London, p. 147.

32) Iferkwunigwe, A. E. (1974): Treatment of severe PCM, in Protein Calorie Malnutrition, ed. by Olson, R. E., Academic Press, New York, p. 389.

33) Suskind, R. (1974): In-patient and out-patient treatment of the child with severe protein calorie malnutrition. in Protein Calorie Malnutrition, ed. by Olson, R. E., Academic Press, New York, p. 403.

34) Behar, M., Veleri, F., Bressavi, R., Arroyave, G., Squibb, R. L., and Scrimshaw, N. S. (1958): Principles of treatment and prevention of severe protein calorie malnutrition in children (kwashiorkor). Ann. N.Y. Acad. Sci., 69, 954.

35) Senegal, J. (1958): The treatment and prevention of kwashiorkor in French West Africa. Ann. N.Y. Acad. Sci., 69, 916.

36) Gomez, F., Ramos-Galvan, R., Cravioto, J., and Frenk, S. (1958): Prevention and treatment of chronic severe infantile malnutrition (kwashiorkor). Ann. N.Y. Acad. Sci., 69, 969.

37) Prinsloo, J. G., Pretorius, P. J., Welmeyer, A. S., De Villier, L. S., Fellingham, S. A., and Kruger, H. (1967): Effect of a low protein milk powder formula on the initiation of cure in kwashiorkor patients. Am. J. Clin. Nutr., 20, 270. 
38) Periera, S. M., Issac, I., Begum, A., Dumm, M. E., and Webb, J. K. G. (1965): Moderate protein and high calorie diets in treatment of kwashiorkor. Ind. Pediatr., 2, 76.

39) Graham, G. G., Cordano, A., and Baerth, J. M. (1963): Effect of protein and calorie intake on weight gain. J. Nutr., 8, 249.

40) Rutishauser, I. H. E., and McCance, R. A. (1968): Calorie requirements for growth after severe undernutrition. Arch. Dis. Childh., 43, 252.

41) Ashworth, A., Bell, R., James, W. P. T., and Waterlow, J. C. (1968): Calorie requirements of children recovering from protein calorie malnutrition. Lancet, ii, 600 .

42) Grimble, R. F., and Whitehead, R. G. (1970): Fasting serum amino acid patterns in kwashiorkor and after administration of different levels of protein. Lancet, i, 918.

43) Gopalan, C. (1974): Protein vs. calorie in the treatment of protein calorie malnutrition: Metabolic and population studies in India, in Protein Calorie Malnutrition, ed. by Olson, R. E., Academic Press, New York, p. 329.

44) Dean, R. F. A. (1965): Recent Advances in Pediatrics, 3rd ed., ed. by Gardner, D., Churchill, London, p. 234.

45) Bowie, M. D., Hansen, J. D. L., and Barbezar, G. O. (1967): Am. J. Clin. Nutr., 20, 89.

46) Wharton, B. A. (1967): Kwashiorkor, initial treatment difficulties. in Calorie Deficiencies and Protein Deficiencies, ed. by McCance, R. A. and Widdowson, E. M., Churchill, London, p. 147.

47) Arroyave, G. (1969): Proposed methodology for the biochemical evaluation of protein calorie malnutrition in children, in Protein Calorie Malnutrition, ed. by Von Muralt, Springer, New York, p. 48. 